\title{
Determination of some heavy metals content in the body of two popular fish species O.niloticus and $L$. niloticus, in lake Nubia,Wadi Halfa, Sudan
}

\begin{abstract}
The study was conducted in Lake Nubia at far North of Sudan to determine the mean contentvalues (ppm) of heavy metals, namely, $(\mathrm{Hg}, \mathrm{Pb}, \mathrm{Cd}, \mathrm{Cu}$, and $\mathrm{Fe})$ in Nile Tilapia (O. niloticus) and Nile perch (L.niloticus) livers and muscles. Fish samples were collected from three main fishing sites in the lake Nubia from north to south: Eshkait, Gimai, and Semna fishing sites, respectively, twice a year during the winter and hot rainy summer seasons of 2016 and 2017. Samples were analyzed for determining the level of heavy metal sex cluding Hgusing the Atomic Absorption apparatus(NOBAA350, ENGLAND). Direct Mercury Analyzer apparatus (DMA-80, USA) was used to determine Hg. Laboratory analysis results of samples were subjected to statistical analysis using SPSS version 16 and means were compared to detect significant differences using the multifactorial method in three different study sites regardless of how high the concentration. The highest $\mathrm{Hg}$ level in $O$. niloticus muscles was found in the Gimai fishing site. The lead level was significantly high in L.niloticus liver in the Eshkait fishing site. The highest levels of $\mathrm{Hg}, \mathrm{Pb}$, and $\mathrm{Cu}$ might reflect the local mining activity nearby to the southern part of the lake and use of bad quality of $\mathrm{Pb}$ in fishing nets at Eshkait.
\end{abstract}

Volume 9 Issue 5 - 2020

\author{
Mubarak Eisa AT,' Ali Awad AM² \\ 'Department of Fisheries Science, University of Bahri, Sudan' \\ ${ }^{2}$ WadiHalfa Fisheries Administration, Northern State, Sudan
}

Correspondence: Mubarak Eisa AT, Department of Fisheries Science, University of Bahri, Sudan, Email mubarktbn@gmail.com

Received: September 25, 2020 | Published: October 22, 2020

Keywords: lake nubia, heavy metals, fishing sites, O.niloticus, L.niloticus

\section{Introduction}

Lake Nubia is the southernpart of the huge man-made lake formed as a result of the construction of a higher Aswan dam (HAD) in Aswan lies in Sudanese territory. The main portion of lies in Egypt as Lake Nasir. Filling started in 1964 and still ongoing fluctuation normally within 5-10meters high. The average annual discharge of the Nile is $84 \times 10^{9} \mathrm{~m}^{3}$. The whole lake with its total storage capacity at $160 \times 10^{9} \mathrm{~m}^{3}$, the volume of water at the present level is around the highest expected 180masl. The lake is located in an extremely dry and hot zone, with no rainfall and high records temperature (sometimes $48^{\circ} \mathrm{C}$ in hot summer. But the water temperature average higher-level $32^{\circ} \mathrm{C}$ with min about $5^{\circ} \mathrm{C} .{ }^{1}$ According to Henderson ${ }^{2}$ morphometric index MEI $(51 \mathrm{~kg} / \mathrm{ha})$; lake Nubia sustainable fish production would be around 5100 metric tons/years. The lake is considered asan important source of fisheries of freshwater fish in Sudan, more than 1444 fishermen gain their living from this fishing sites besides loading and reloading truck drivers depend on the lake in their living. ${ }^{3}$ The lake is rich in biodiversity where it lodges more than 26 fish species belong to 10 families were recorded. Nile perch (Latus niloticus), Bagrusbayad, Nile tilapia (Oreochromis niloticus), Synodontis schall, Clarias gariepinus, tiger fish, Hydrocyanic, and other species. ${ }^{4}$

Lake Nubia has witnessed, during the recent years, a huge activity of gold mining, where formerly this gold mining was done by using metal detector machines or devices on the outer shell of the earth, then it turned to dig of deep wells and extraction of crushed stones, washed by water and then the use of mercury to separate gold from impurities, which has led to the leak of mercury to the Lake directly through the showering of the mining workers and washing of the vehicles. In February 2015, some fish mortality occurred in Akasha and Dal areas where samples were taken from the water and dead fishes and then sent to the Sudan University of Science and Technology laboratories for analysis where the results showed the presence of mercury at high concentrations. The significance of the study appears from the importance of Lake Nubia as a natural capture fishery that supports a huge subscription to the national gross product of fish. Moreover, all those who are concerned with fishing (Fishermen, traders, laborers) will be subjected to a very strong knock or even loss of earnings, it provides or reflects environmental disasters that may take place. In general, the study aim to evaluate the level of heavy metals in samples taken from the main three fishing areas of the Nubian lake, however, the specific objectives were: to determine the heavy metals $(\mathrm{Hg}, \mathrm{Pb}, \mathrm{Cd}, \mathrm{Cu}$, and $\mathrm{Fe})$ in experimental samples taken from fish to determine the levels of heavy metals in two fish species $O$. niloticus and L.niloticus samples collected from the three fishing sites, Akasha, Gimai and Semna

\section{Brief review on Lake Nubia}

Lake Nubia is located within the desert zone in northern Sudan. the North African Sahara zone (i.e. Egypt and Northern Sudan), where the lake is located considered as the aridest regions of the world. ${ }^{5}$ The larger part of the area is an absolute desert with almost no vegetation. It receives on average less than $0.1 \mathrm{~mm}$ rainfall per year. The Nubia Lake is divided into two zones; the riverine zone (between Akasha and Duweishat) and the semi-riverine zone (between Duweishat and latitude 220). During the period 2005-2014, the mean annual air temperature recorded for the summer (May to July) was $47.2^{\circ} \mathrm{C}$ and that recorded for the winter (December to February) was $5.7^{\circ} \mathrm{C}$. The maximum air temperature was $49.5^{\circ} \mathrm{C}$ recorded in May 2011 and the minimum was $4.0^{\circ} \mathrm{C}$ recorded in January 2012 . The monthly average 
values of summer air temperature ranged from $39.9^{\circ} \mathrm{C}$ recorded in 2009 to $41.8^{\circ} \mathrm{C}$ recorded in 2010 while that of winter ranged from $4.0^{\circ} \mathrm{C}$ recorded in 2011 to $7.0^{\circ} \mathrm{C}$ recorded in 2010 . Generally the monthly average temperature ranged from $25.0^{\circ} \mathrm{C}$ to $28.1^{\circ} \mathrm{C}$ relative humidity at the same period was ranged between $12 \%-95 \%$. The highest value was recorded in October 2010 and the lowest value was recorded in May 2014.No rainfall was recorded around Lake Nubia during the last decade (2005-2014) except for 2010, 2011, and 2013 when a value of $5.0 \mathrm{~mm}$ rainfall was measured during August. The maximum wind speed of $34 \mathrm{~km} / \mathrm{h}$ was reported in March 2006 and 2013 and in November 2007 while the lowest wind speed was $<1$ $2 \mathrm{~km} / \mathrm{h}$ (Lake Nasser/Nubia (LNN) Management Framework Project, 2014).

\section{Approaches and challenges to pollution management in Lake Nubia}

Challenges that hinder the control of Nubian lake water pollution by traditional mining activities through the wash of mercury remnants in water stream at Dolgo, Sowarda, and Akasha mining sites, moreover farmers along the Nile are accustomed to using herbicides and pesticide which in turn are washed into the lake during flood season and cause high fish mortalities. Thousands of old landfills and dumpsites exist throughout the developing countries representing a threat to human health for the next decades unless appropriate measures are taken. Most developing countries follow the practice of open dumping of solid wastes causing environmental and health risks. ${ }^{6}$ Industrialization, population growth, and unplanned urbanization have partially or turned our environment into dumping sites for waste materials. ${ }^{7}$ From a single interview visit the farmers who work in the Semnna area for up to 25 years stated that there are intensive agricultural activities particularly growing off-season Tomatoes using pesticides and herbicides in large quantities, in the flood season the land submerged resulting incomplete washing.

\section{Heavy metals in fish}

According to Samir and Shakir ${ }^{8}$ the concentration of heavy metals in fish gills and liver is much higher than that in muscles. Similar finding was reported by Yuyu et al. ${ }^{9}$ when they found that livers of the three fish species (Carassiusauratus, Pelteobagrus fulvidraco, and Squaliobarbus curriculum) were collected from Xiang River near Changsha City, Southern Chinawas accumulated with $\mathrm{Cd}$ and $\mathrm{Cu}$ due to the metallothionein proteins. Moreover, they thought that the presence of a high level of heavy metals in gill indicates that the main uptake pathway of these heavy metals was from the water These proteins are thought to play an important role in protecting them from damage by heavy metal toxicants. Also, gills are the site directly exposed to the ambient conditions and also are known for their excretory function even for some metals like zinc. ${ }^{9}$ In a study carried in four Arctic lakes in Alaska by Susan et al., the maximum concentrations of most metals in fish from this study are equal to or higher than those collected from remote Arctic lakes and rivers in Canada, Finland, and Russia. Muscle Hg Lake. Concentrations above $1 \mathrm{~g} / \mathrm{g}$ wet weight were observed in lake trout from Feniak.

Moreover, Saleh ${ }^{10}$ reported that the amount of pollutants in the fish liver is directly proportional to the degree of pollution in the aquatic environment by heavy metals. Similar observations were reported by many studies carried out with various fish species. ${ }^{11,12}$ Accumulation of metals in various organs of fish may cause structural lesions and functional disturbances. ${ }^{13}$ Adverse effects of metals on fish are related not only to material accumulation, but also to cumulative toxic effect. Exceeding certain values of metal 5 concentration in fish results in lethal disturbances. In most cases, fish from metal-contaminated water is safe for human consumption due to low metal accumulation (except for mercury) in the muscle tissue. However, such fish may constitute a potential risk for predatory fishes, birds, and mammals feeding on contaminated fish. The environmental factors affect the uptake and accumulation of metals in fish. According to Kocket al., ${ }^{14}$ cadmium and lead levels in Salvelinus alpinus liver and kidneys indicate higher uptake rates of both metals in summer when the water temperature was higher. The authors explained that with an increased metabolic rate. The data obtained by Douben ${ }^{15}$ indicate that the rate of uptake and elimination of cadmium by Noemacheilus barbatulus increased with water temperature, the author suggested that stronger effect of temperature on metal absorption than on elimination. Various species of fish from the same water body may accumulate different amounts of metals. Interspecies. Differences in metal accumulation may be related to living and feeding habits. Kidwell et al. ${ }^{16}$ observed that predatory fish species accumulated more mercury but the benthivores contained more cadmium and zinc. Higher concentrations of mercury in the predatory fishes comparing to the non-predatory ones were also reported by Voigt Ney and Van Hassel ${ }^{17,18}$ found that lead and zinc concentrations were higher in benthic fish. The results obtained by Campbell ${ }^{19}$ indicate that predators accumulated more zinc and nickel than benthivores, while the latter contained more cadmium. Liver accumulates high concentrations of metals, Irrespectively of the uptake route. The liver is considered a good monitor of water pollution with metals since their concentrations accumulated in this organ are often proportional to those present in the environment. That is especially true for copper and cadmium. Metal levels in the liver rapidly increase during exposure, 6 and remain high for a long time of depuration, when other organs are already

\section{Hazardous effects of heavy metals on human health}

Metals can contaminate the general environment through many routes. Because of their stability, they may penetrate environmental compartments, in some cases, many years after the initial deposition pollution of the soil and water systems may also arise from the weathering of the disposed of the product. Heavy metal accumulations in plants and soil from natural and artificial sources and subsequent consequences represent important environmental pollution problems. Food safety issues and potential adverse health risks make this one of the most serious environmental concerns. Some heavy metals such as copper, zinc, manganese, cobalt, and molybdenum act as micronutrients for the growth of animals and human beings when present in trace quantities, whereas others such as cadmium, arsenic, and chromium act as carcinogens. Mercury and lead are associated with the development of abnormalities in children Gibb and Chen et al., have reported that long term intake of cadmium causes renal, prostate, and ovarian cancers. Generally, at the biochemical levels, the toxic effects caused by excess concentrations of heavy metals include competition for sites with essential metabolites, replacement of essential ions, reactions with -SH groups, damage to cell membranes, and reactions with the phosphates groups.

\section{Materials and methods}

\section{Study sites}

The study was conducted in Lake Nubia northern of the Sudan which lies between Argin Village in the north (N21.999396 
$\left.\mathrm{E} 31.303530^{\circ}\right)$ to Dal village in the south $\left(\mathrm{N} 20.978042^{\circ}, \mathrm{E} 30.56930^{\circ}\right)$. It's of an area of $180 \mathrm{~km}, 17 \mathrm{~km}$ width at the North and narrows Southwards, for the purpose of this study we divided it into three parts (Map 3.1,below):

Gimai fishing site north Wadi Halfa at the border with Egypt, $\left(\mathrm{N} 21.842793^{\circ}, \mathrm{E} 31.309977^{\circ}\right)$, average width $10 \mathrm{~km}$, its surrounded by rock, no vegetation on either side of the lake rarely sparse vegetation on either side .characterized by weak water current due to its vicinity to the high Dam.
Semna fishing siteextends $30 \mathrm{~km}$ to the South of Halfa $\left(\mathrm{N} 21.656351^{\circ}, \mathrm{E} 31.164747^{\circ}\right)$ with a width of $5 \mathrm{~km}$, considered the best fishing site because of the extension of the lake at either side during flood season, the area is surrounded by water herbs, bushes and 21 shrubs on both sides. The current is moderate during autumn, but when water comes down the lake farmers grow the previously watercovered land with Watermelon and Tomatoes, they extensively use herbicides and pesticides which will be drained to lake causing fish mortalities (Figure 1)

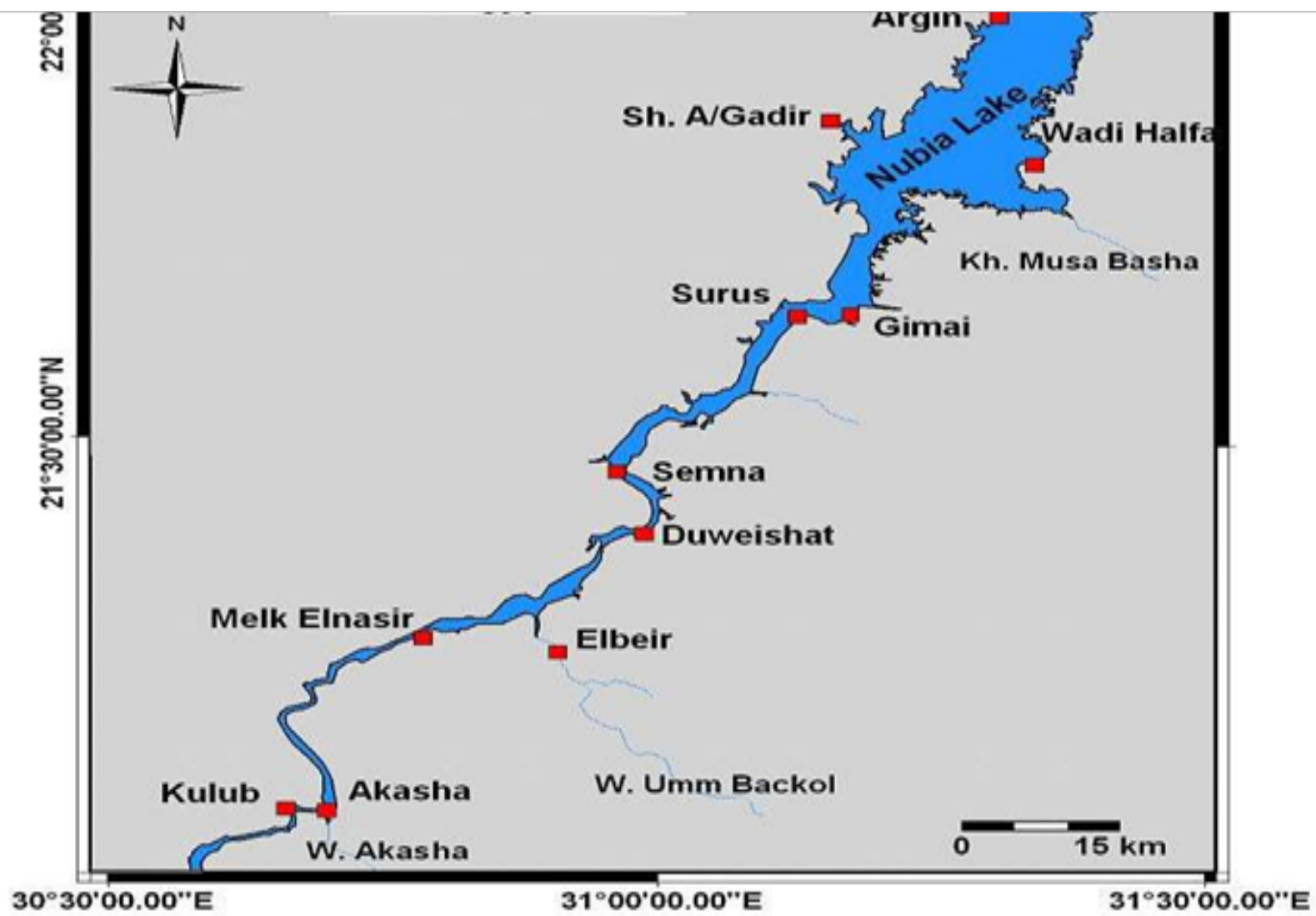

Figure I Shows the three sampling sites, namely, Eshkait north at the border with Egypt, Semna in the middle, and Akasha in South.

Akasha site, It lies $60 \mathrm{~km}$ south of Halfa (N21.47291, E30.95722 ${ }^{\circ}$ ) with a width of $2 \mathrm{~km}$, water current is strong and the lake is narrower. It's considered as an important agricultural area as well it's inhabited by many mining companies and traditional mining activities that extend to the South of this are where they gather along valleys during the dry season, and al remnants of mining drained to lake leading to drastic consequence.

\section{Fish samples collection and preparation for analysis}

A total of fifty samples from each fish species were collected from landing sites twice per year during the Winter (April) and Summer (October) seasons of 2016 and 2017. Five to ten grams of fresh liver and muscles of fish two sub-samples were dissected and sent immediately Petroleum laboratories belong to the ministry of mining in Khartoum for $\mathrm{Hg}$ concentration detection. For the detection of four targeted heavy metals $(\mathrm{Pb}, \mathrm{Cd}, \mathrm{Fe}$, and $\mathrm{Cu})$ the second group of sub-samples was sent to Veterinary research laboratories at Soba, Khartoum

\section{Analysis procedure for mercury and other heavy metals}

The livers and muscle samples were extracted by digestion using a modified method of Seymoreet al. ${ }^{20}$ One gram of sub-sample was placed into a $200 \mathrm{ml}$ flask and $20 \mathrm{ml}$ of nitric acid and $5 \mathrm{ml}$ perchloric acid was added. Then contents were heated for $12 \mathrm{~h}$ at $225^{\circ} \mathrm{C}$ (increased gradually) on a hotplate and evaporated to $\sim 5 \mathrm{ml}$. When the samples formed a clear liquid, $0.2 \mathrm{ml}$ of lanthanum chloride $(100 \mathrm{~g}$ $\mathrm{La} / \mathrm{L}$ solution) was added. The volume was then made up to $20 \mathrm{ml}$ with $2 \% \mathrm{HNO}$. A reagent blank was produced using the same procedure using an atomic absorption spectrophotometer.

\section{Statistical analysis}

All obtained data were analyzed using a one-way analysis of variance according to statistical analysis system software (SPSS, 16 ,). Statistical analytical involved the analysis of mean data of heavy metal concentrations in fish tissues, from three fishing sites using 
multiple analysis of variances in the Lake Nubia. to evaluate collected and analyzed to measure the impact of the heavy metals in lake Nubia.A multiple range test (Duncan's, 1955) ${ }^{21}$ was used to compare the parameters of the different nutritional groups. The differences were significant at 0.05 levels.

\section{Results}

Mercury mean values in Fish liver and muscles at the three different fishing sites

Figure 2 below shows that the highest values of Mercury in the liver $(0.1505 \pm 0.172 \mathrm{ppm})$. and muscles $(0.0982 \pm 0.087 \mathrm{ppm})$ were recorded in Gima fishing sites,

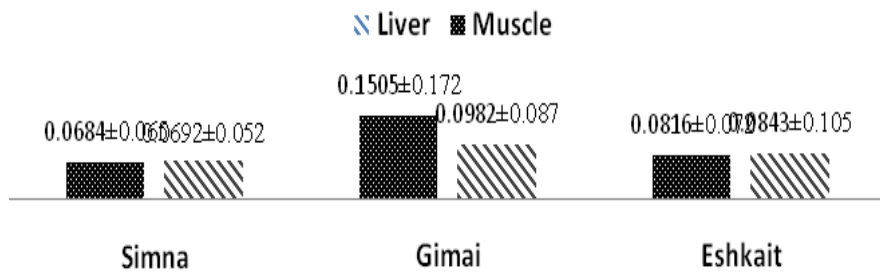

Figure 2 Shows the mercury values in fish liver and muscles at the three different fishing sites, Simna, Gimai and Eshkait.

Mercury mean values in $O$. niloticus and L. niloticus liver and muscles at summer and winter

Mercury's highest mean value in fish liver and muscles was recorded forL.niloticus, in Winter, as shown in Figure 3 below.

III O.niloticus $\&$ L.niloticus

\begin{tabular}{|c|c|c|c|}
\hline & & & $0.172 \pm 0.125$ \\
\hline & $0.0852 \pm 0.065$ & $0.0943 \pm 0.085$ & Yysy \\
\hline $0.0166 \pm 0.006$ & 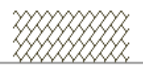 & & (7) \\
\hline
\end{tabular}

Figure 3 Shows the mercury mean values in two fish species liver and muscles during the summer and Winter seasons in Lake Nubia.

Lead mean value in Fish liver and muscles at the three different fishing sites

Figure 4 below shows that the highest mean values of lead in the liver $(0.2816 \pm 0.0230 \mathrm{ppm})$. and muscles $(0.2395 \pm 0.120 \mathrm{ppm})$ were recorded in Eshkait fishing sites,

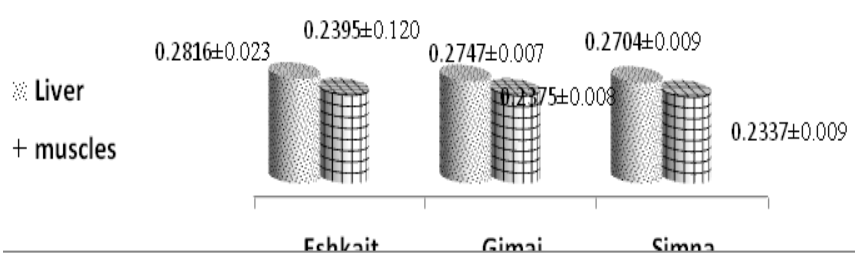

Figure 4 Shows the lead mean values in fish liver and muscles at the three different fishing sites, Simna, Gimai, and Eshkait (2016- 2017).

Lead mean values in $O$. niloticus and $L$. niloticus liver and muscles at summer and winter

Lead highest mean value in fish liver and muscles was recorded for O.niloticus, in Winter, as shown in Figure 5 below.

Cadmium mean values content in Fish liver and muscles at the three different fishing sites

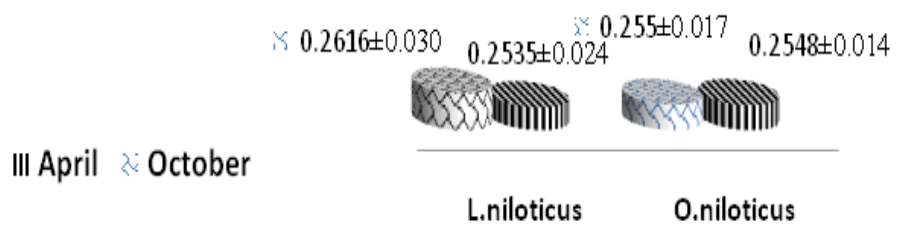

Figure 5 Show the lead mean values in two fish species liver and muscles during summer and winter seasons in Lake Nubia from 2016 to 2017.

Figure 6 below shows the highest mean values content of cadmium in the liver $(0.2800 \pm 0.0050 \mathrm{ppm}$ and $0.0283 \pm 0.0050)$ were recorded in Gimai and Eshkait fishing sites, respectively.

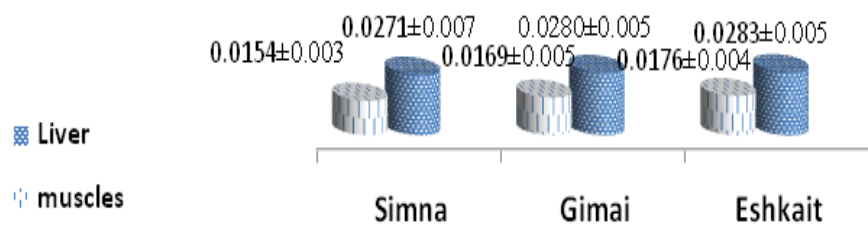

Figure 6 Shows the cadmium mean values in fish liver and muscles at the three different fishing sites, Simna, Gimai and Eshkait.

Cadmium mean values in $O$. niloticus and L. niloticus liver and muscles at summer and winter

Figure 7, below shows cadmium mean values for all fishing sites was higher for samples of L.niloticusand O. niloticusin April ( $0.024 \pm 0.007 \mathrm{ppm}$ and $0.0222 \pm 0.007 \mathrm{ppm}$ ) compare to that found in October $(0.0218 \pm 0.008 \mathrm{ppm}$ and $0.0209 \pm 0.007)$, respectively.

\begin{tabular}{|c|c|c|c|}
\hline $\begin{array}{l}\text { NO.niloticus } \\
\text { L.niloticus }\end{array}$ & 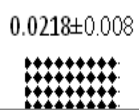 & $0.0209 \pm 0.007$ & $\begin{array}{c}0.024 \pm 0.008 \\
0\end{array}$ \\
\hline & Oct & & \\
\hline
\end{tabular}

Figure 7 Shows the cadmium mean values in two fish species samples during summer and winter seasons in Lake Nubia from 2016 to 2017.

Copper mean values content in Fish liver and muscles at the three different fishing sites

As shown in figure 8 below, no significant difference in mean content values of copper in the liver and muscles of each species from the three fishing sites of lake Nubia.

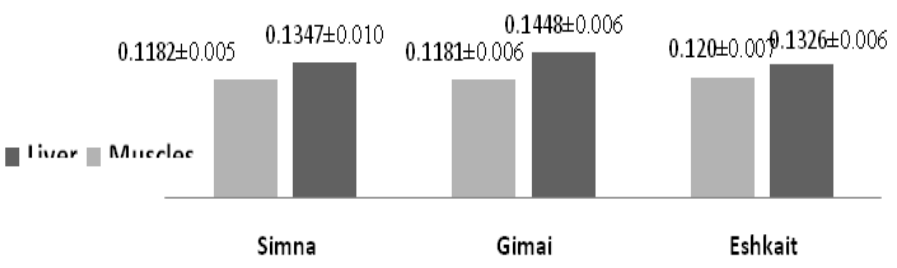

Figure 8 Shows the copper mean values in fish liver and muscles at the three different fishing sites, Simna, Gimai and Eshkait.

Copper mean values in $O$. niloticus and L. niloticus liver and muscles at summer and winter

Figure 9 below shows copper mean values for all fishing sites was higher for samples of L.niloticus and O. niloticusin April ( $0.024 \pm 0.007 \mathrm{ppm}$ and $0.0222 \pm 0.007 \mathrm{ppm})$ compare to that found in October $(0.0218 \pm 0.008 \mathrm{ppm}$ and $0.0209 \pm 0.007)$, respectively. 


\section{茨 0. niloticus $=$ L.niloticus}

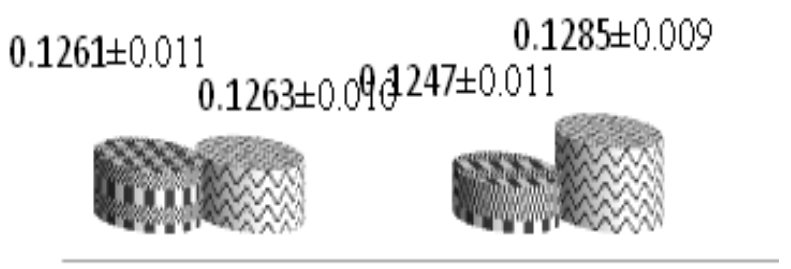

October

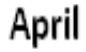

Figure 9 Shows the mean content values of copper for two fish species samples during Summer andWinter seasons in Lake Nubia from 2016 to 2017.

Concentration of Iron $(\mathrm{Fe})$ in fish tissues at different fishing sites

The highest ironvalue content highest in the liver of fish was found in the Eshkait fishing site $(1.2594 \pm 0.03 \mathrm{ppm})$ where the least value content of iron( $1.1353 \pm 0.01751 \mathrm{ppm})$ was reported for fish muscle at the Gimai fishing site Figure 10.

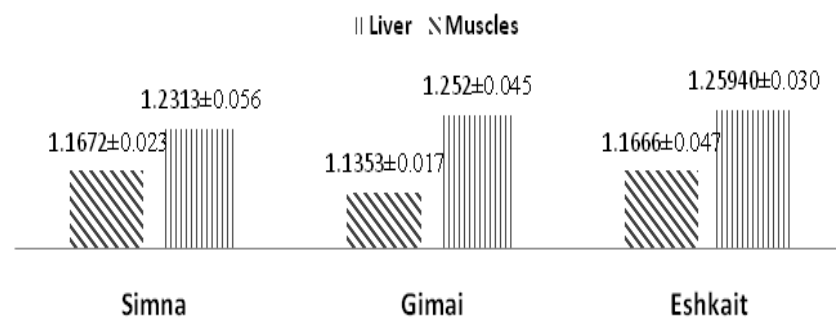

Figure 10 Shows the iron mean values in fish liver and muscles at the three different fishing sites, Simna, Gimai and Eshkait.

Iron mean values content in $O$. niloticus and L. niloticus liver and muscles at Summer and Winter

Figure 11, below shows the mean iron content value in was found higher (1.2175 $\pm 0.068 \mathrm{ppm})$ during April compared to that of the same fish species during October (1.19290.059 ppm).

\begin{tabular}{|c|c|c|}
\hline $\begin{array}{l}\text { \% O.niloticus } \\
\text { L.niloticus }\end{array}$ & $\begin{array}{c}1.1929 \pm 0.055 \\
\% 1 / \% 1.1982 \pm 0.059 \%\end{array}$ & 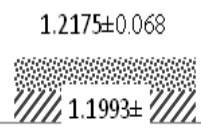 \\
\hline & October & April \\
\hline
\end{tabular}

Figure I I Shows the iron means content values for two fish species samples during summer and winter seasons in Lake Nubia from 2016 to 2017.

\section{Discussion}

Mercury content values determined in fish tissues collected from the three fishing sites in Lake Nubia was found still low when compared to that detected from tissues of $O$. niloticus in Egypt $(0.45 \mathrm{ppm})$ as reported by Khallaf et al., ${ }^{22}$ Lesser content value of mercury $(0.011 \mathrm{ppm})$ was reported from Sri Lanka by Jinadasa and Edirisinghe. ${ }^{23}$ Justification of the high content value of mercury in the Gimai fishing site might be attributed to the traditional mining activities going on there where mercury is used in gold mining processes. The high content value of mercury in L.niloticus tissues is understood as it is known as one of the top predator fish in Lake Nubia. Eshkait fishing site where the fishermen from Sudan and Egypt used to use bad quality of lead as sinkers for their fishing nets. This type of unstandardized lead usually inter to the Sudanese market through smuggling and find its way to the hand of fishermen in Lake Nubia. Lead and copper content values detected in tissues of fish samples in Lake Nubia in this study is found to be higher compared to content values them from White Nile $(0.1206 \pm 0.007 \mathrm{ppm}, 0.2382 \mathrm{ppm}$, respectively) as reported by Angela. Cadmium content value was found to be higher $(0.0473 \mathrm{ppm})$ in $O$. niloticus tissue compared to the content value of the same species from Lake Nubia ${ }^{24}$ irrespectively to fishing sites. Iron was found to be high in all three fishing sites. The variation in content values of nearly most of the studied heavy metals was noticed. Seasonal floods might carry a load of heavy metals to the mainstream of The River Nile from mining areas south to fishing sites and mining areas barrel to fishing sites east to the bank of the lake. The mean content values of those heavy metal exceeding the codex, particularly, mercury is alarming. More focused studies are an urgent need to investigate the exact causes behind the increase in the level of heavy metals beyond the international codex. Involve of officials and all stakeholders are normally but highly required. The health problems and complain of citizens regarding the unorganize and unplan traditional mining growing. The high mean value content of mercury in livers and muscles of the one of the top predator fish (L. niloticus), in the lake is agreed with the findings of Kidwell et al. ${ }^{16}$ were observed that predatory fish species accumulated more mercury but the benthivores contain more cadmium and zinc. According to Campbell ${ }^{19}$ concluded that the liver could be considered a good monitor of water pollution with metals..$^{25}$

\section{Conclusion}

The level of heavy metals in Nubia lake is alarming which exceeded the international codex, particularly mercury concentration in commercial fish flesh. Attention is highly required by central, local government bodies, and all stakeholders. Furthermore, studies are needed to expand detect other heavy metals in water, Lake Nubia bottom deposits, Phyto, and zooplankton.

\section{Acknowledgments}

Great thanks to fishermen at three fishing sites and Fisheries Administration Officers and Workers at Wadi Halfa Locality, Northern State, Sudan for their logistic support and facilitation throughout the whole period of this study.

\section{Funding \\ None.}

\section{Conflicts of interest}

The author declares that there is no conflicts of interest.

\section{References}

1. Ali. MA. Final report for DAL Group submitted by ALTAIR consultancy, October. 2016

2. Henderson H.F. The fish of reservoirs of central Sudan.Cairo, FAO Report. 1975.

3. Northern State Report. Annual report of fisheries \& aquatic management. 2017.

4. Northern State Report. Annual report of fisheries \& aquatic management. 2003.

5. Wickens GE. Palaeobotanical speculations and Quaternary environments in Sudan. In: Williams MAJ and DA Adamson editors. A L and Between Two Niles. Quaternary geology and biology of Central Sudan. Rotterdam. AA Balkema. 1982;23-50. 
6. Kurian J, Esak KUS, Palanivelu K, et al. Studies on landfill mining at solid waste dumpsites in India. In: MARGHERITA DI PULA, S., editor. Ninth International Waste Management and Landfill Symposium, 2003 Italy Proceedings Sardinia 2003;6-10.

7. Ikem A, Osiobanjo O, Sridhar MKC, et al. Evaluation of groundwater quality characteristics near two waste sites in Ibadan and Lagos, Nigeria. Water, Air, and Soil Pollution. 2002;140:307-333.

8. Samir, Shakir. Assessment of Heavy Metals Pollution in Water and Sediment and their Effect on Oreochromisniloticus in the Northern Delta Lakes, EGYPT. 8th International Symposium on Tilapia in aquaculture. $2008 ; 479-483$

9. Matthiessen P, Brafield AE. Uptake and loss of dissolved zinc by stickleback Gasterosteusaculeatus (L). J Fish Biol. 1977;10(4):399-410.

10. Saleh HH. Fish liver is an indicator of aquatic environmental pollution. Bull Inst Oceanogr \& Fish. 1982;8 (1):69-79.

11. Guerrin F, Burgat-Sacaze V, Saqui- Sames P. Levels of heavy metals and organochlorine pesticides of cyprinid fish reared four years in wastewater treatment pond. Bull Environ Contam Toxicol. 1990;44: 461- 467.

12. Saeed SM, Sakr SF. Impact of cage- fish culture in the river Nile on Physico- chemical characteristics of water, metals accumulation, histological, and some biochemical parameters in fish. Abbassa Int $J$ Aqua. 2008;(1A): 179-202.

13. Jezierska B, Witeska M. Metal Toxicity to Fish. Wydawnictwo Akademii Podlaskiej, Siedlce. 2001; p. 318 .

14. Kock G, Triendl M, Hofer R. Seasonal patterns of metal accumulation in Arctic char (Salvelinusalpinus) from an oligotrophic Alpine lake related to temperature. Can J Fish Aquat Sci. 1996;53(4):780- 786.

15. Douben PET. Uptake and elimination of waterborne cadmium by the fish Noemacheilusbarbatulus L. (stone loach). Arch Environ Contam Toxicol. 1989; 18: 576-586.
16. Kidwell JM, Phillips LJ, Birchard GF. Comparative analyses of contaminant levels in bottom- feeding and predatory fish using the national contaminant biomonitoring program data. Bull Environ Contam Toxicol. 1995;54(6):919-923.

17. Voigt HR. Concentrations of mercury $(\mathrm{Hg})$ and cadmium $(\mathrm{Cd})$, and the condition of some coastal Baltic fishes. Environmentalist Fennica. 2004; 21: p. 26.

18. Ney JJ, Van Hassel JH. Sources of variability in accumulation of heavy metals by fishes in a roadside stream. Arch. Environ. Contam. Toxicol. 1983;12(6):701-706.

19. Campbell LM, Dixon DG, Hecky RE. A review of mercury in Lake Victoria, East Africa: Implications for human and ecosystem health. $J$ Toxicol Environ Health part B. 2003;6(4):325- 356.

20. Seymore H, Du Preez HH, Van Vuren JHJ. Concentrations of zinc in Barbusmarquess from the lower Oli fants River, Mpumalanga, South Africa. Hydrobiologia. 996;332:141-150.

21. Duncan DB. Multiple ranges and multiple F tests. Biometrics. 1955;11:142.

22. Khallaf EA, Galal M, Authman M. The biology of Oreochromisniloticus in a polluted canal. Journal of Ecotoxicology. 2003;12: 405- 416.

23. Jinadasa BKKK, Edirising he EMRKB. Cadmium, lead and total mercury in Tilapia sp. in Sri Lankan reservoirs, Food Additives \& Contaminants: Part B. Survellance. 2014;7:(2):90-94.

24. Lake Naser/Nubia manament report, Lake Nasser/Nubia (LNN) Management Framework and Guidelines Project. UNESCO Chair in Water Resources, Sudan, Development Research and Technological Planning Center (DRTPC), Egypt. Final Draft report (version 3), 2015.

25. Jia Y, Wang L, Qu Z, et al. Effects on heavy metal accumulation in freshwater fishes: species, tissues, and sizes. Environ SciPollut Res. 2017;24:9379-9386. 